\title{
The Relationship Between Spiritual Comfort with Emotion Regulation of Patients with Diabetes Mellitus in Kalibagor Public Health Center in Banyumas
}

\author{
$1^{\text {st }}$ Arni Nur Rahmawati \\ Health Science Faculty \\ Harapan Bangsa University \\ Purwokerto, Indonesia \\ arninr@uhb.ac.id
}

\author{
$2^{\text {nd }}$ Ririn Isma Sundari \\ Health Science Faculty \\ Harapan Bangsa University \\ Purwokerto, Indonesia \\ ririnismasundari@uhb.ac.id
}

\author{
$3^{\text {rd }}$ Budiyanto \\ Kalibagor Public Health Center \\ Purwokerto, Indonesia \\ budiyanto.ners@gmail.com
}

\begin{abstract}
Chronic diseases, including Diabetes Mellitus, are stressors for individuals. This will affect the emotion regulation of individual. Individuals need a source of coping to solve the stressors, one of which is spirituality. Spiritual comfort will help individuals adapt to stressors so as to produce adaptive coping mechanisms. This study was aimed to analyze the relationship between spiritual comfort with the emotional regulation of Diabetes Mellitus patients in Kalibagor Public Health Center in Banyumas. Quantitative correlation research design with cross-sectional approach was applied in this study. The study samples were $82 \mathrm{DM}$ patients in Kalibagor Public Health Center. The results found 69 respondents $(84.1 \%)$ had high spiritual comfort, $58(70.7 \%)$ had high emotion regulation. There is a relationship between spiritual comfort with emotion regulation with a p-value of 0,000 which is smaller than alpha, with the strength of relationship is strong $(0.736)$. The higher the spiritual comfort is, the higher the emotion regulation in most $\mathrm{DM}$ patients is. $\mathrm{A}$ high spiritual comfort and emotion regulation are one source of positive belief coping to overcome stressors in DM patients.
\end{abstract}

Keywords: diabetes mellitus, emotion regulation, spiritual comfort

\section{INTRODUCTION}

Diabetes mellitus (DM) is a non-communicable disease characterized by the body inability to carry out metabolism of carbohydrates, fats, and proteins causing hyperglycemia [1]. The International of Diabetic Federation (IDF) mentions the global prevalence of DM sufferers aged 20 to 79 years in 2015 was 415 million people. In 2017, it increased by 425 million people. In Indonesia, according to the results of the Basic Health Research (Riskesdas) in 2013 the age group above 15 years was diagnosed by doctors experiencing DM by $1.5 \%$ [2]. This increased dramatically in 2018, the results of Riskesdas showed that DM sufferers diagnosed by doctors in Indonesia reached $2.0 \%$. The prevalence of DM is also calculated based on the 2015 Consensus routine blood tests for residents over 15 years, with a result of $10.9 \%$ of sufferers [3]. Central Java is one of the provinces with a prevalence rate above the national rate.

Symptoms of DM vary widely, ranging from mild symptoms to severe symptoms. Some of the symptoms that are often found in patients with DM are in the form of excessive thirst (polydipsy), frequent urination (polyuri), often feel hungry (polypagi), weight loss rapidly, complaints of weakness, tingling in the hands and feet, itching, blurred vision, impotence, difficult to heal wounds, vaginal discharge, fungal skin diseases under the folds of the skin, and in mothers often found giving birth to large babies with birth weight above 4,000 grams [4].

DM also causes psychosocial problems. Stuart in the Stress Adaptation Model believes that physical health problems are stressors for the occurrence of psychosocial problems for individuals. Physical complaints, especially complications in DM patients such as the presence of gangrene wounds, amputatum conditions, glaucoma, damage to kidney function, will disrupt the patient's selfconcept. This is a psychological aspect stressor [5]. Furthermore, from the social aspect, DM symptoms that are felt will limit patients in their activities, including efforts to earn a living, must regulate diet and exercise patterns, and even sexual dysfunction can occur. One of the psychosocial problems that is often experienced by patients with chronic diseases such as DM is depression.

Riskesdas in 2018 states that in Indonesia the prevalence of depression reaches $6.1 \%$ of the population aged over 15 years [3]. Ramdani's research conducted at Kardinah City Hospital in Tegal found that $15.2 \%$ of DM patients had mild depression and $2.5 \%$ had moderate depression. Depression that occurs for a long time and does not get the right treatment can cause patients to fall into a state of disruption so it must be prevented [6]. Emotion regulation is one of the factors that influence the coping mechanism of patients in dealing with problems, including depression. 
Emotional regulation is the ability possessed by individuals to assess, overcome, manage, and express the right emotions in order to achieve emotional balance [7][9]. Emotion regulation is very important in helping to maintain the health of DM patients. In DM patients, a stimulus or stressor activates the HPA axis which is reflected by the release of corticotrophin-releasing hormone $(\mathrm{CRH})$ and vasopressin by the paraventricular nucleus from the hypothalamus. This stimulates the production of adrenocorticotropic hormone $(\mathrm{ACTH})$ by the anterior pituitary gland, then triggers the release of cortisol which will affect insulin function in terms of sensitivity, production and receptors, so blood glucose cannot be balanced [9], [10]. In dealing with this stressor DM patients will use their coping resources, one of which is a positive belief in which spirituality is a component.

Bradle et al. in 2011 show that spiritual comfort has an impact on spiritual well-being when it is the focus of attention on health care [11]. Winarto in 2018 argues that spiritual comfort includes 3 dimensions, the intrapersonal dimension, the interpersonal dimension, and the transpersonal dimension. Spiritual comfort is an important aspect for an individual's health in relation to dealing with pain experiences and therapeutic regimens during illness [12]. This is needed by DM patients, because DM is a chronic disease that will continue to stick with individuals throughout their lives. With good spiritual comfort, it is hoped that DM patients can achieve a constructive coping mechanism in dealing with a set of symptoms they experience and adhere to the DM management protocol.

Presurvey was held in April 2019 in the work area of Kalibagor Health Center in Banyumas Regency. The number of patients who participated in the Chronic Disease Management Program (PROLANIS) was 82 DM patients. Of the $10 \mathrm{DM}$ patients interviewed, 8 of them said they did not know what God planned for their lives, 7 said they were confused about the direction of their lives, 9 of them said they often got prejudiced about what happened in their lives. Coaching conducted by Kalibagor Health Center in collaboration with BPJS Health in DM patients one of which is the Chronic Disease Management Program (PROLANIS). This activity has been routinely carried out every month, in the form of education, monitoring of blood sugar levels, group activities in the form of DM exercises, reminders conducted to DM patients regarding medication adherence and medication services. Data related to psychospiritual problems and emotional regulation experienced by DM patients is not yet available in Kalibagor Health Center. Therefore, researchers plan to conduct research on the relationship of spiritual comfort with the emotional regulation of DM patients in the Work Area of the Kalibagor Health Center in Banyumas Regency.

Previous studies have been conducted related to psychosocial problems in DM patients have been quite a lot. Wulandari in 2017 examined the relationship of self- compassion with emotion regulation in patients with DM [13]. Another study conducted by Syarif in 2017 about the relationship of family support with emotional regulation in DM patients. The research that has been done only connects the source of coping aspects of personal ability and social support as an independent variable with the regulation of emotions as the dependent variable [14]. Stuart suggests that the source of coping is not only personal abilities and social support, but also positive beliefs, namely spiritual [5]. In Indonesia, research related to spiritual comfort has only been conducted on HIV positive patients. Therefore, this study was aimed to determine the relationship of spiritual comfort with emotional regulation in DM patients.

\section{METHOD}

This study employed a descriptive correlative research design with a cross-sectional approach (measurements were made at one time). The population in this study was all 82 DM patients who actively participated in PROLANIS activities. The sampling technique used was total sampling. The sample size in this study were $82 \mathrm{DM}$ patients. This research was conducted in the work area of Kalibagor Public Health Center in Banyumas Regency from May to June 2019 with the ethical research from RSUD Banyumas.

Univariate analysis was performed by presenting the results of each variable with a frequency distribution. Bivariate analysis was used to test hypotheses between independent and dependent variables. Bivariate analysis in this study was conducted using the Pearson Product Moment correlation test because the data were normally distributed to determine the relationship of spiritual comfort with emotional regulation in DM patients in the work area of Kalibagor Public Health Center.

\section{RESULTS AND DisCUSSION}

1. Characteristics of Age, Gender, and Duration of Diabetes Mellitus in Diabetes Mellitus Patients in the Work Area of Kalibagor Health Center, Banyumas

Table 1.1 Characteristics of Age and Duration of Diabetes Mellitus in Diabetes Mellitus Patients in the Work Area of Kalibagor Health Center,

\begin{tabular}{|l|c|c|c|c|c|}
\hline \multicolumn{1}{|c|}{ Variablel } & n & Mean & Median & SD & Min-Max \\
\hline Age & 82 & 62,89 & 61,50 & 8,68 & $41-79$ \\
\hline Durasi of DM & 82 & 8,00 & 9,00 & 4,00 & $1-11$ \\
\hline
\end{tabular}

Based on table 1.1 it is known that the average age of DM patients in the Work Area of Kalibagor Banyumas Health Center is 62.89 years with the youngest age is 41 years and the oldest age is 79 years. The average length of patient had DM is 8 years with the shortest DM experience last 1 year and the longest 11 years. 
Table 1.2 Characteristics of Gender of Diabetes Mellitus in Diabetes Melitus Patients in the Work Area of Kalibagor Health Center, Banyumas

\begin{tabular}{|l|c|c|}
\hline Gender & Frequency & Percentage \\
\hline Male & 33 & 40,2 \\
\hline Female & 49 & 59,8 \\
\hline Total & 82 & $100 \%$ \\
\hline
\end{tabular}

Table 1.2 shows that the majority of DM patients in the work area of Kalibagor Banyumas Health Center was 49 female (59.8\%) respondents, the rest were male.

2. A description of the Spiritual Comfort of Diabetes Mellitus Patients in the Work Area of Kalibagor Health Center, Banyumas

Table 2.1 Spiritual Comfort of Diabetes Mellitus Patients in the Work Area of Kalibagor Health Center, Banyumas

\begin{tabular}{|}
\multicolumn{4}{|c|}{ Area of Kalibagor Health Center, Banyumas } \\
\hline Spiritual Comfort & Frequency & Percentage \\
\hline High & 69 & 84,1 \\
\hline Low & 13 & 15,9 \\
\hline Total & 82 & $100 \%$ \\
\hline
\end{tabular}

Table 2.1 shows that the majority of DM patients in the working area of Kalibagor Banyumas Health Center have high spiritual comfort as many as $69(84.1 \%)$ and the remaining low as many as $13(15.9 \%)$.

3. Description of Emotional Regulation for Diabetes Mellitus Patients in the Work Area of Kalibagor Health Center in Banyumas

Table 3.1 Emotion Regulation of Diabetes Mellitus Patients in the Work Area of Kalibagor Health Center, Banyumas

\begin{tabular}{|c|c|c|}
\hline Emotion Regulation & Frequency & Percentage \\
\hline High & 58 & 70,7 \\
\hline Low & 24 & 29,3 \\
\hline Total & 82 & $100 \%$ \\
\hline
\end{tabular}

Table 3.1 shows that the majority of DM patients in the working area of Kalibagor Banyumas Health Center have high emotional regulation of 58 $(70.7 \%)$ and the remaining low of $24(29.3 \%)$.

4. Relationship between Spiritual Comfort and Emotion Regulation for Diabetes Mellitus Patients in the Work Area of Kalibagor Health Center in Banyumas

Table 4.1 Relationship between Spiritual Comfort and Emotional Regulation of Diabetes Mellitus Patients in the Work Area of Kalibagor

\begin{tabular}{|c|c|c|c|}
\hline \multicolumn{1}{|c}{ Health Center, Banyumas } \\
$\begin{array}{c}\text { Variable } \\
\text { independent }\end{array}$ & $\begin{array}{c}\text { Variable } \\
\text { dependent }\end{array}$ & P-Value & $\begin{array}{c}\text { Pearson } \\
\text { Correlation }\end{array}$ \\
\hline Spiritual comfort & Emotion regulation & 0,000 & 0,736 \\
\hline
\end{tabular}

Based on table 4.1 it is found that spiritual comfort is associated with emotional regulation in DM patients with a $\mathrm{P}$ value of 0.000 smaller than alpha, with a strong relationship strength (0.736). The direction of the positive relationship, which means the higher the spiritual comfort, the higher the emotional regulation of the respondent.

The age characteristics of respondents in the study conducted in the Kalibagor Banyumas Community Health Center were 62.89 years with the youngest age 41 years and the oldest age 79 years. Diabetes Mellitus (DM) is a chronic disease caused by an imbalance in blood glucose levels. Multi etiological consequences. Age is one of the risk factors for DM. Increasing the age of an individual will result in a decrease or damage to body organs, including the pancreas. This results in the body experiencing both absolute and relative insulin insufficiency. This is in line with the results of Isnaini \& Ratnasari's research (2017) that most patients with DM are in the age group above 45 years of age totaling $76(72 \%)$ respondents [15]. In this study most of the respondents at an average age of 62.89 years were not only due to organ damage related to increasing age, but also because respondents were taken during the implementation of Prolanis followed by the age group of pralansia and the elderly. This causes the age range of respondents $40-79$ years.

The average length of patient had DM 8 years with the shortest DM experience last 1 year and the longest 11 years. In line with Restada's research (2016), it was shown that the long duration of suffering from DM was mostly in the moderate category (6-10 years) with $32(36 \%)$ respondents, while the short duration was $29(32.5 \%)$ respondents and the long duration was 28 ( $31.5 \%)$ respondents. Closely related to age risk factors, that DM is a chronic disease that is triggered by increasing age due to damage to pancreatic function, the onset of DM often occurs when individuals enter the age of pralansia (40 years) [16]. In fact, active prolanist participants attended were in the average age of 62 years, so that the average length of DM experience was 8 years.

DM, which is a chronic disease, has complications that will predispose to stress in individuals. Therefore, we need an adequate coping source to overcome them. Spirituality is one source of solution and is believed to be the most influential source of resolution with individual coping mechanisms. Most DM patients in the work area of Kalibagor Banyumas Health Center have high spiritual comfort i.e. 69 people $(84.1 \%)$ and the rest are low with 13 people $(15.9 \%)$.

Spiritual definition has 3 main attributes, namely internal strength in humans that are non-physical in the form of meaning of life, peace of life and belief in power that is beyond human reach. The meaning of life in individual spirituality is a belief held by an individual about the nature of his existence in the world. The subsistence spirituality of the meaning of life in Islam believes in the nature of human existence on earth, namely to worship. This aspect is manifested in religious activities of humans carrying out the commands of worship directly to Allah that has been ordered through His messenger, as well as aspects of worship that are realized through relationships with fellow beings around him. Beliefs about the meaning of life in Islam, whatever is done and however the living conditions solely carry out the obligation to worship the Creator of man himself. 
The peace subsystem is a condition of interconnection between humans and forces beyond human reach. It is who has life here and after and governs and has absolute power over humans and all beings. Peace will be realized when the interconnection can be applied perfectly. Human connection with the Creator, human connection with fellow humans and humans with creatures around them. Peace reflects the conditions of complete interconnection. Thus, peace can be identified with prosperity. Well-being is defined as a feeling of feeling whole and healthy, according to one of the criteria for feelings of being a whole and wellbeing [10].

Spirituality in the subsistence of life beliefs begins with knowledge and understanding of the creation of all beings and humans themselves. Confidence in the existence of a Creator that does not begin and end. The belief about the existence of rules for the harmony of life of all beings brought through Allah's messenger. Islam encapsulates the faith in the six pillars of Islam to be adhered to by followers not as dogma. The manifestation of that belief is applied in the worship activities of its adherents. This spiritual comfort will form an individual coping mechanism that is manifested in the form of emotional regulation [12], [17].

Emotion regulation is the capacity to control and adjust emotions that arise at the right level of intensity to achieve a goal. Appropriate emotional regulation includes the ability to regulate feelings, physiological reactions, cognition related to emotions, reactions related to emotions [18]. Gross (2007) states that emotional regulation is a strategy that is done consciously or unconsciously to maintain, strengthen or reduce one or more aspects of emotional responses, namely emotional experience and behavior. Someone who has emotional regulation can maintain or increase the emotions he feels, both positive and negative [8], [18], [19].

In this study the majority of DM patients in the working area of Kalibagor Banyumas Health Center had high emotional regulation of $58(70.7 \%)$ and the remaining low of $24(29.3 \%)$. Individuals are said to be able to regulate emotions if they have good enough control of emotions that arise. The ability of emotion regulation can be seen in the six skills namely self-control, having good interpersonal relationships with others, having a cautious attitude, having adaptability, higher tolerance for frustration, having a positive view towards themselves and their environment [18].

Spiritual comfort is associated with emotional regulation in DM patients with a p-value of 0,000 less than alpha, with the strength of a strong relationship (0.736). The direction of the positive relationship, which means the higher the spiritual comfort, the higher the emotional regulation of the respondent. This is in line with the theory put forward by Stuart (2013) that to deal with stressors individuals need sources of coping which include personal abilities, social support, material assets, and positive beliefs. Spiritual is included in the source of positive faith coping[5].

Spirituality as a noun is defined as the essence of being human or the essence of the purpose of human life, which is pervasive or impregnated in someone's life, which gives awareness about "what" and "who" they are, and what is a source of internal strength, which shapes a person's life [20]. It is a personal question to understand an answer to the last question about life, about meaning, about relationships that are sacred or beyond human reach. Thus, spirituality is owned by every individual, both those who claim to embrace certain religions and individuals who declare themselves not to embrace religion.

\section{CONCLUSION}

Spiritual comfort has a strong relationship with emotion regulation in DM patients. If spiritual comfort is high, emotion regulation is also high in most DM patients. A high spiritual comfort and emotion regulation are one source of positive belief coping to overcome stressors in DM patients.

\section{ACKNOWLEDGMENTS}

The authors thank Kalibagor Public Health Center for the opportunity to do this research and also all of DM patient who were willing to be respondents in this study.

\section{REFERENCES}

[1] Y. M. Sulistria, "Tingkat Self care Pasien Rawat Jalan Diabetes mellitus tipe 2 di Puskesmas Kalirungkut Surabaya," J. Ilm. Mhs. Univ. Surabaya, vol. 2, no. 2, pp. 1-11, 2013.

[2] Depkes RI, “Riset Kesehatan Dasar 2013,” Jakarta, 2014.

[3] Depkes RI, “Riset Kesehatan Dasar 2018,” Jakarta, 2019.

[4] Brunner \& Suddarth, Buku Ajar Keperawatan Medikal Bedah Edisi 8 Volume 2. Jakarta: EGC, 2013.

[5] G. W. Stuart, Principles and practice of psychiatric nursing, 10th Ed. Missouri: Mosby Elsevier, 2013.

[6] M. Ramdani, "Gambaran Tingkat Depresi Pada Pasien Diabetes Melitus Tipe 2 di Rumah Sakit Umum Kardinah KotaTegal," Universitas Islam Negeri Syarif Hidayatullah Jakarta, 2016.

[7] K. R. Roy, "STRESS , APPRAISAL, AUTONOMOUS SUPPORT AND COPING : AN INTEGRATIVE PERSPECTIVE OF ADULT TYPE 2 DIABETES MANAGEMENT IN NEWFOUNDLAND AND by," Memorial University of Newfoundland, 2018.

[8] A. J. Aldao, Amelia; Plate, "Coping and Emotion Regulation," in Process-Based CBT: The Science and Core Clinical Competencies of Cognitive Behavioral Therapy, S. G. H. Steven C. Hayes, Ed. New Harbinger Publications, 2018, p. 480. 
Sokaraja," Universitas Muhammadiyah Purwokerto, 2017.

[15] R. R. N Isnaeni, "Faktor resiko mempengaruhi kejadian Diabetes Mellitus tipe 2," J. Kebidanan dan Keperawatan Aisyiyah, 2018.

Communal Coping Model," Health Commun., vol. 33, no. 6, pp. 690-699, 2018.

[10] A. L. Marroquín, Brett;Tennen, Howard; and Stanton, "Coping, Emotion Regulation, and Well-Being: Intrapersonal and Interpersonal Processes," in The Happy Mind: Cognitive Contributions to Well-Being, M. D. Robinson and M. Eid, Eds. Springer International Publishing, 2017, pp. 1-480.

[11] J. M. Bredle, J. M. Salsman, S. M. Debb, B. J. Arnold, and D. Cella, "Spiritual well-being as a component of health-related quality of life: The Functional Assessment Of Chronic Illness Therapy-Spiritual Well-Being Scale (FACIT-Sp)," Religions, vol. 2, no. 1, pp. 77-94, 2011.

[12] E. Winarto, "Konstruksi Instrumen Kenyamanan Spiritual Pada Pasien HIV Positif di Beberapa Rumah Sakit Jawa Tengah,’ Universitas Indonesia, 2019.

[13] H. Wulandari, "Hubungan antara Self-Compassion dengan Regulasi Emosi pada Pasien Diabetes Mellitus Tipe 2 di RSUD dr R. Goeteng Taroenadibrata Purbalingga," 2017.

[14] R. Syarif, "Hubungan antara Dukungan Sosial dengan Regulasi Emosi Pasien Diabetes Mellitus di Komunitas Prolanis
E. . Restada, "Hubungan Lama Menderita Dan Komplikasi Diabetes Melitus Dengan Kualitas Hidup Pada Penderita Diabetes Melitus Di Wilayah Puskesmas," Universitas Muhammadiyah Surakarta, 2016.

[17] T. T. Sytsma, L. A. Schmelkin, S. M. Jenkins, L. A. Lovejoy, M. I. Lapid, and K. M. Piderman, “Keep the faith': Spirituality as a contributor to resiliency in five elderly people," J. Relig. Spiritual. Aging, vol. 30, no. 4, pp. 314-324, 2018.

[18] R. A. Gross, J. J., \& Thompson, "Emotion Regulation: Conceptual Foundations," in Handbook of emotion regulation, In J. J. G., New York: The Guilford Press, 2007, pp. 3-24.

[19] A. Gyurak, J. J. Gross, and A. Etkin, "Explicit and implicit emotion regulation: A dual-process framework," Cogn. Emot., vol. 25, no. 3, pp. 400-412, 2011.

[20] Q. T. T. Wallace M., Campbell S., Grossman S.C., Shea J.M., Lange J.W., "Integrating Spirituality Into Undergraduate Nursing Curricula," Int J Nurs Educ, 2008. 